\title{
Pengembangan Psikomotorik Peserta Didik melalui Kegiatan Outing Class di BA Aisyiyah Bulakrejo 2, Sukoharjo
}

\author{
Choiriyah Widiasari ${ }^{1}$, Humaam Almahi ${ }^{2}$, Dewi Prasetyoningrum ${ }^{3}$, Nisa Laili Rohmatika ${ }^{4}$, Evera Nia- \\ ra Sendy ${ }^{5}$, Yudhistira Laksamana Satria ${ }^{6}$, Jati Ayu Nurma Permatasari ${ }^{7}$, Rosalia Tunika Grandis ${ }^{8}$, \\ Ara Reda Astara ${ }^{9}$, Muhammad Edi Kurniawan ${ }^{10}$

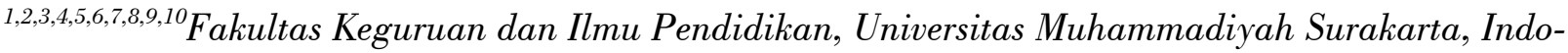 \\ nesia
}

\section{INFORMASI ARTIKEL}

\section{Histori Artikel:}

Submit: 27 April 2020

Revisi: 2 Mei 2020

Diterima: 4 Mei 2020

Publikasi: 6 Mei 2020

Periode Terbit: Desember 2019

\section{Kata Kunci:}

pembelajaran diluar kelas, pendidikan anak usia dini, psikomotorik

\section{Correspondent Author:}

Humaam Almahi

Fakultas Keguruan dan Ilmu Pendidikan

Universitas Muhammadiyah Surakarta,

Indonesia

Email: humaamalmahi@gmail.com

\begin{abstract}
ABSTRAK
Pendidikan merupakan poin utama dalam memajukan suatu bangsa dan negara, sesuai dengan tujuan pendidikan yang terdapat pada UndangUndang Sistem Pendidikan Nasional Republik Indonesia. BA Aisyiyah Bulakrejo 2 merupakan suatu lembaga pendidikan yang berada di bawah naungan Aisyiyah yang berfokus pada pendidikan anak usia dini. Pendidikan anak usia dini merupakan usia yang sangat penting dalam pertumbuhan dan perkembangan seorang anak usia dini. Perkembangan anak usia dini meliputi lima ranah, yakni kognitif, fisik motorik, bahasa, emosi sosial dan Seni. Perkembangan psikomotorik merupakan perkembangan yang penting untuk dikembangkan, salah fungsinya untuk mengasah kemampuan mototik halus dan kasar seorang anak. Salah satu program pembelajaran yang dapat dilakukan untuk mengembangkan perkembangan fisik motorik khususnya motorik kasar pada anak adalah dengan kegiatan outing class. Kegiatan outing class cukup efektif dalam mengoptimalkan perkembangan psikomotorik anak. Kegiatan outing class dilakukan dengan kegiatan outbound. Lokasi pelaksanaan outbound dilakukan didekat sekolah. Kegiatan Outbound dirancang untuk mengembangkan motorik kasar anak, selain itu juga bermanfaat untuk mengembangkan aspek yang lain yakni perkembangan kognitif, emosi, sosial, bahasa dan juga seni. Aspek yang dikembangkan dalam permainan psikomotik tersebut meliputi pengembangan nilai kerja keras, mandiri, berpikir cepat, dan kerjasama anak usia dini.
\end{abstract}

\section{Pendahuluan}

Pendidikan saat ini menjadi suatu hal yang sangat penting, karena pendidikan merupakan poin utama dalam memajukan suatu bangsa dan negara. Pendidikan akan membentuk sumber daya manusia yang berkualitas secara intelektual dan berkarakter. Tujuan pendidikan tersebut tertuang dalam UndangUndang Sistem Pendidikan Nasional Republik
Indonesia yang berbunyi "Pendidikan Nasional berfungsi mengembangkan kemampuan dan membentuk watak serta peradaban bangsa yang bermartabat dalam rangka mencerdaskan kehidupan bangsa dan bertujuan untuk berkembangnya potensi peserta didik agar berakhlak mulia, sehat, berilmu, cakap, kreatif, mandiri, dan menjadi warga negara yang demokratis serta bertanggung jawab". Maka dari itu alangkah 
doi: $10.23917 /$ bkkndik.v1i2.10775

lebih baik apabila pendidikan dilakukan atau diterapkan sejak dini melalui Pendidikan Anak Usia Dini (PAUD). Lebih lanjut menurut dalam Permendikbud nomor 37 tahun 2014 dijelaskan bahwa PAUD merupakan pendidikan yang ditujukan pada anak usia untuk merangsang dan memaksimalkan aspek-aspek perkembangannya. Terdapat 6 aspek perkembangan yang harus dikembangkan oleh guru Pendidikan Anak Usia Dini (PAUD). Keenam aspek tersebut adalah aspek perkembangan nilai agama dan moral, koginitf, sosial emosional, Bahasa, fisik motorik, dan seni (Kemendikbud, 2014).

Pendidikan Anak Usia Dini atau PAUD adalah suatu upaya pembinaan yang ditujukan bagi anak sejak lahir sampai dengan usia 6 tahun yang dilakukan dengan memberi rangsangan pendidikan untuk membantu pertumbuhan dan perkembangan jasmani dan rohani agar anak memiliki kesiapan dalam memasuki pendidikan lebih lanjut. Pendidikan anak usia dini dirasa sangat penting untuk menumbuhkan pertumbuhan yang optimal, memiliki kecerdasaan secara intelektual, spiritual, emosional, serta meningkatkan potensi yang ada di dalam diri peserta didik. Pendidikan yang baik tentu tidak hanya bersumber terhadap aspek nilai tetapi pendidikan yang sesuai dengan pertumbuhan dan perkembangan anak. Perkembangan dan pertumbuhan memiliki arti yang sama yakni keduanya memiliki arti perubahan, tetapi secara khusus pertumbuhan memiliki arti pertumbuhan mengandung definisi perubahan ukuran secara fisik yang bersifat pasti akurat atau dapat diartikan sebagai akibat dari perubahan kematangan dan kesiapan fisik yang melakukan suatu aktivitas. Catron dan Allen dalam Yuliani Nuraini Sujiono (2009) mengemukakan bahwa terdapat 6 aspek perkembangan anak usia dini, yaitu: kesadaran personal, pengembangan emosi, membangun sosialisasi, pengembangan komunikasi, pengembangan kognitif, dan pengembangan kemampuan motorik. Ke enam aspek tersebut dapat diterapkan melalui pembelajaran di dalam kelas maupun diluar kelas. Pembelajaran di luar kelas dirasa cukup efektif dalam mengoptimalkan pertumbuhan dan perkembangan yang ada dalam diri siswa apalagi terkait perkembangan secara psikomotorik karena psikomotorik merupakan awal dari kecerdasan dan emosi sosial sehingga gerakan secara motorik sangat penting atau menjadi fokus utama. Gerakan motorik adalah suatu istilah yang digunakan untuk menggambarkan perilaku gerakan yang dilakukan oleh tubuh manusia (Hasanah, 2016). Kecerdasan secara motorik haruslah diasah semaksimal mungkin dalam pendidikan anak usia dini melalui kegiatan bermain di luar kelas. Aspek perkembangan motorik pada anak usia dini telah ditentukan indikatornya melalui Standar Tingkat Pencapaian Perkembangan Anak (STPPA) yang tercantum dalam Permendikbud 137 tahun 2014 sesuai dengan tingkat usia. STPPA adalah kriteria tentang kemampuan yang dicapai anak pada seluruh aspek perkembangan dan pertumbuhan (Kemendikbud, 2014)

Bermain memiliki pengaruh yang sangat besar bagi perkembangan seorang anak. Anakanak tidak perduli apakah kondisi fisik dan psikis bagus atau tidak, semuanya dilakukan dengan senang, karena pada hakikatnya bermain adalah kebutuhan bagi anak. Oleh karena itu, peran orang tua dan guru dibutuhkan dalam memberikan arahan dan pengawasan. Orang tua dan guru juga berperan dalam memilihkan permainan. Steve Stork dan Stephen W. Sanders (2008: 197-199) mengatakan aktivitas fisik 
sangat penting untuk pertumbuhan perkembangan secara keseluruhan pada anak. Mengoptimalkan penguasaan keterampilan dan sikap yang dapat menyebabkan perilaku yang lebih sehat dalam hidup, dan juga memfasilitasi perkembangan kognitif dan sosial, perkembangan fisiologis yang unik dan pengembangan neurologis terhadap anak usia dini.

Outing class juga melatih siswa untuk belajar secara langsung dengan alam dan lingkungan di sekitarnya. Pembelajaran di luar kelas diterapkan sesuai tema yang ada. Kegiatan yang dilakukan dapat berupa outbound, kunjungan di tempat-tempat yang berkaitan dengan tema pembelajaran kelas, atau bahkan hanya mengajak siswa untuk berkeliling di lingkungan sekitar.

Saat ini lembaga pendidikan sudah banyak yang mengaplikasikan outing class dengan mengajak anak-anak dengan kegiatan outbound. Salah satu lembaga pendidikan yang menerapkan pembelajaran di luar kelas ialah BAAisyiyah Bulakrejo 2 Sukoharjo. Akan tetapi, kurang dan minimnya sarana dan prasana serta tenaga pengajar menjadikan kegiatan kurang maksimal dan optimal. Maka dari itu berdasarkan latar belakang di atas perlu adanya variasi kegiatan pembelajaran di luar kelas yang dapat mengoptimalkan psikomotorik peserta didik dalam pendidikan anak usia dini. Tujuan dari Artikel dibuat adalah untuk mengoptimalkan perkembangan psikomotorik anak usia dini melalui kegiatan outing class.

\section{Metode Pelaksanaan}

Pengabdian ini dilakukan di BA-Aisyiyah Bulakrejo 2 selama kurang lebih 1,5 bulan mulai dari 22 Januari sampai dengan 3 Maret 2020. Tahapan pengabdian ini pelaksanaannya berupa observasi, dokumentasi serta catatan lapangan pada saat peserta didik melakukan aktivitas outing class. Sasaran pengabdian ini ialah peserta didik BA-Aisyiyah Bulakrejo 2 yang berjumlah 15 anak.

\section{Hasil Pelaksanaan dan Pembahasan}

BA-Aisyiyah Bulakrejo 2 merupakan lembaga pendidikan formal untuk anak usia dini. BA-Aisyiyah 2 terdiri dari 15 peserta didik dan satu orang kepala sekolah yang merangkap menjadi tenaga pengajar. Usia peserta didik berkisar antara 4-6 tahun. Gedung BA-Aisyiyah Bulakrejo 2 masih berada di salah satu rumah warga di dukuh Curidan RT 02 Desa Bulakrejo. Adanya gedung yang masih menumpang di rumah warga menjadi suatu keterbatasan tersendiri terkait kurang maksimalnya sarana prasarana yang ada. Hal tersebut juga yang menjadikan enggannya orang tua mempercayakan putra putrinya untuk bersekolah di BAAisyiyah 2 Bulakrejo sehingga peserta didik hanya berasal dari lingkungan sekitar. Itupun tidak semua anak-anak di lingkungan tersebut bersekolah di BA-Aisyiyah 2, orang tua cenderung lebih memilih sekolah di luar yang dianggap baik untuk pendidikan putra putrinya. Keterbatasan sarana prasarana yang tersedia seperti kurang lengkapnya alat peraga atau media pembelajaran bagi anak TK membuat proses pembelajaran tidaklah maksimal. Maka dari itu untuk mensiasati proses pembelajaran perlu adanya alternatif pembelajaran agar peserta didik dengan mudah dalam memahami materi belajar yang ada. Salah satu alternatif yaitu dengan memanfaatkan lingkungan sekitar melalui outing class. Outing class yaitu pembelajaran outing class dengan memanfaatkan lingkungan yang ada. Kegiatan tersebut diantaranya 
berupa outbound, kunjungan pada instansi tertentu, dan mengajak peserta didik jalan-jalan untuk melihat lingkungan sekitar.

BA Aisyiyah Bulakrejo 2 merupakan lembaga pendidikan formal yang menaungi peserta didik usia dini dengan rentang usia 4 hingga 6 tahun. Rentang usia tersebut ialah usia emas atau golden age bagi tumbuh kembang anak. Upaya menumbuh kembangkan potensi yang dimiliki peserta didik salah satunya bisa melalui pengembangan psikomotorik yang ada dalam diri peserta didik. Pengembangan secara psikomotorik dirasa menjadi hal yang sangat penting. Pengembangan secara psikomotorik dapat melalui proses pembelajaran di luar maupun di dalam kelas (Ratih, K., et al, 2019). Pembelajaran di luar kelas atau outing class dirasa cukup efektif dalam menumbuh kembangkan psikomotorik anak. Adanya keterbatasan sarana prasarana seperti yang dialami BAAisyiyah 2 bulakrejo tentu outing class menjadi alternatif yang efektif dan efisien dalam mendukung perkembangan psikomotorik anak khususnya motorik kasar. Kegiatan outing class juga memiliki manfaat dalam mengembangkan kecerdasan naturalistik, dimana anak belajar mengenai fenomena alam yang ada disekitarnya. Anak mampu melihat secara langsung kondisi alam yang dekat dengannya, seperti melihat tanaman, hewan, serangga dan kondisi alam yang ada lainnya Maryanti, (2009). Kegiatan outing class dirancang, disusun bersama antara guru BA Bulakrejo 2 bersama dengan mahasiswa KKN-DIK FKIP UMS. Kegiatan outing class dirancang dalam bentuk outbound. Menurut menurut Djamaluddin Ancok (2000:3) bahwa outbound adalah kegiatan di alam terbuka (outdoor), outbound juga dapat memacu semangat belajar. Outbound merupakan sarana penambah wawasan pengetahuan yang didapat dari serangkaian pengalaman berpetualang sehingga dapat memacu semangat dan kreatifitas anak. Bentuk kegiatan outbound berupa stimulasi kehidupan melalui permainan (games) yang kreatif, rekreatif, dan adukatif, baik secara individual maupun kelompok, dengan tujuan untuk pengembangan diri anak didik.

Dengan kegiatan outbound terlihat antusiasme peserta didik BA Aisyiyah Bulakrejo dalam menjalankan kegiatan tersebut. Hal ini dibuktikan dengan kehadiran yang tanpa ada yang ijin dan juga keikutsertaan aktif para peserta didik.

Kegiatan outbound juga memberikan kontribusi positif terhadap kesuksesan belajar. Hal ini dibuktikan oleh pernyataan Asti (2009) yang menyatakan bahwa outbound memiliki berbagai macam keuntungan seperti: memberikan pengalaman langsung kepada peserta didik, penuh kegembiraan karena dilakukan dengan berbagai permainan edukatif yang menyenangkan dan memberikan dampak positif bagi salah satu peserta didik yang mungkin saja mengalami masa kecil kurang bahagia.

Outbound juga merupakan salah satu sarana yang bisa digunakan untuk menambah wawasan pengetahuan siswa yang didapatkan dari serangkaian pengalaman seperti berbagai lomba yang dilaksanakan pada waktu outbound.

Kegiatan outbound tidak harus dilakukan di tempat arena outbound yang memang sudah dirancang namun juga bisa memanfaatkan lingkungan sekitar untuk kegiatan tersebut. Seperti kegiatan outbound yang dilakukan kali ini dengan mengunakan lahan kosong warga yang berada di dekat sekolah sebagai lokasi outbound. Kegiatan outbound yang dilakukan bersama peserta didik BA-Aisyiyah Bulakrejo 2 
bertujuan untuk mengembangkan psikomotorik anak. Adapun aspek perkembangan yang ingin ditingkatkan adalah nilai kerja keras, mandiri, berpikir cepat, dan kerjasama peserta didik. Adapun kegiatan dilakukan dengan konsep bermain seperti estafet karet, menyusun puzzle, pukul air, estafet air, dan estafet bendera. Permainan yang ada dalam outbound tersebut melatih peserta didik, utamanya merangsang perkembangan motorik naun juga mengembangkan aspek perkembangan yang lain pada anak.

Dari hasil amatan yang dilakukan para peserta didik terlihat cukup aktif mengikuti permainan. Setiap permaianan menunjukkan hasil bahwa peserta didik mampu melakukan kegiatan dengan baik. Harapannya stimulasi yang dilakukan melaui kegiatan outbon ini dapat mengembangkan empat nilai yang ingin dikembangkan yakni nilai kerja keras, mandiri, berpikir cepat, dan kerjasama.

\section{Simpulan}

BA Aisyiyah Bulakrejo 2 Sukoharjo merupakan lembaga pendidikan formal untuk anak-anak usia dini dengan kisaran usia antara 4 hingga 6 tahun. Anak-anak dengan usia tersebut termasuk dalam kategori golden age atau usia keemasan, di mana fase pertumbuhan dan perkembangan ditentukan dalam usia tersebut. Melalui pendidikan anak usia dini diharapkan peserta didik dapat mengoptimalkan dan memaksimalkan tumbuh kembangnya. Optimalisasi tumbuh kembang dapat dirangsang melalui gerakan motorik. Menumbuhkan psikomotorik dapat melalui pembelajaran di dalam kelas melalui media pembelajaran ataupun pembelajaran di luar kelas atau outing class melalui kegiatan outbound. Kegiatan outing class dirasa cukup efektif dalam merangsang psikomotorik anak karena anak dapat mengekspresikan gerakan secara nyata, selain itu adanya keterbatasan sarana prasarana yang dimilliki sekolah terkait media pembelajaran menjadi solusi atau alternatif yang bisa dilakukan untuk mensiasati kekurangan tersebut. Motorik memiliki dua jenis, yaitu motorik kasar dan motorik halus. Pengabdian ini memfokuskan pada bahasan tentang motorik kasar. Ada beberapa pendapat dari beberapa ahli, menurut John W. Santrock (2012:145) mengungkapkan Kemampuan motorik kasar (gross motor skills) meliputi kegiatan otot-otot besar seperti menggerakkan lengan dan berjalan. Kemampuan motorik kasar aktivitas yang menggunakan otot-otot besar, meliputi gerak dasar lokomotor, non lokomotor, dan manipulatif. Kegiatan outing class cukup efektif dalam mengoptimalkan perkembangan psikomotorik anak. Kegiatan outing class dilakukan dengan kegiatan outbound. Lokasi pelaksanaan outbound dilakukan didekat sekolah. Kegiatan Outbound dirancang untuk mengembangkan motorik kasar anak, selain itu juga bermanfaat untuk mengembangkan aspek yang lain yakni perkembangan kognitif, emosi, sosial, bahasa dan juga seni. Aspek yang dikembangkan dalam permainan psikomotik tersebut meliputi pengembangan nilai kerja keras, mandiri, berpikir cepat, dan kerjasama anak usia dini.

Pertumbuhan dan perkembangan secara psikomotorik peserta didik merupakan hal yang begitu penting karena awal dari suatu kecerdasan intelektual, sosial, dan emosional. Maka dari itu perlu suatu strategi pembelajaran yang dapat merangsang psikomotorik peserta didik baik melalui media ataupun kegiatan lainnya. Adanya keterbatasan terkait sarana dan prasarana yang ada di BA-Aisyiyah Bulakrejo 2 Su- 
koharjo tidak menjadi suatu halangan karena terdapat alternatif lain yaitu melalui kegiatan outing class. Maka dari itu bagi sekolah yang memiliki keterbatasan akan sarana dan prasarana seharusnya lebih mengembangkan kegiatan pembelajaran di luar kelas dengan seperti melihat lingkungan di sekitar mereka, menanam tanaman, outbound, ataupun kunjungan pada tempat tempat tertentu.

\section{Daftar Pustaka}

Adyanto, P. (2018). Pendidikan Karakter Anak Usia Dini Menjadi Lebih Mandiri Melalui Bermain Bahan Alam. Almufida.

Asti, B.M. 2009. Fun Outbound, Jogjakarta: Diva Press.

Djamaludin, Ancok. (2003). Outbound Management Training. Yogyakarta: UII

Halida. (2012). Penerapan Model Networked Jejaring dalam Pembelajaran Terpadu Pendidikan Anak Usia Dini. Jurnal Visi Ilmu Pendidikan.

Hasanah, U. (2016). Pengembangan Kemampuan Fisik Motorik Melalui Permainan Tradisional Bagi Anak Usia Dini. Jurnal Pendidikan Anak.

Hidayati, E. (2008). Hubungan Pengetahuan Ibu Tentang Perkembangan Psikomotorik Anak Usia 3-5 Tahun DI Desa Sarirejo Kec. Guntur Kab Demak. Jurnal Keperawatan.

John W Santrock. (2012). Perkembangan Anak. Jakarta: Erlangga.
Kemendikbud, R. I. (2014). Permendikbud Nomor 137 Tahun 2014 Tentang Standar Nasional Pendidikan Anak Usia Dini.

Moh Fauziddin (2018) Useful of Clap Hand Games for Optimalize Cogtivite Aspects in Early Childhood Education. Jurnal Obsesi: Jurnal Pendidikan Anak Usia Dini. Volume 2 Issue 2 (2018) Pages 162-169

Purnama, S. (2016). Materi-materi pilihan dalam parenting education menurut Munif Chatib. Jurnal Ilmiah Tumbuh Kembang Anak Usia Dini, 1(1), 1-16. http://ejournal.uin-

su-

ka.ac.id/tarbiyah/index.php/goldenage/a rticle/view/1245

Rakhmawati, I. (2015). Mengembangkan Kecerdasan Anak Melalui Pendidikan Usia Dini. Smp 1 Undaan Kudus.

Ratih, K., Prayitno, H. J., Sutopo, A., Tamatea, L., \& Syahriandi, M. (2019). Preparing for Quality EFL Teachers: The Disjuncture Between Policies and Practice in The Internet Communication Technology (ICT) Use in Classroom Context.

Selfa Maryanti, (2019) Meningkatkan Kecerdasan Naturalis Anak Melalui Metode Pembelajaran Outing Class Pada Kelompok B Tk Asyiyah X Kota Bengkulu. Jurnal Ilmiah Potensia, 2019, Vol. 4 (1), 22-31 